\title{
INOVASI LAYANAN BERBASIS TEKNOLOGI INFORMASI PADA RUMAH SAKIT SEBAGAI BENTUK REFORMASI BIROKRASI
}

\author{
SERVICES INNOVATION BASED ON INFORMATION TECHNOLOGY IN HOSPITAL AS \\ A FORM OF BUREAUCRATIC REFORM
}

\author{
Arif Sofianto \\ Badan Perencanaan Pembangunan, Penelitian dan Pengembangan Provinsi Jawa Tengah \\ Jl. Pemuda Mo 127 - 133, Semarang, Jawa Tengah \\ Email: 01arifsofianto@gmail.com \\ Diterima: 19 Maret 2020, Direvisi: 2 Mei 2020, Disetujui: 28 Mei 2020
}

\begin{abstract}
ABSTRAK
Salahsatu wujud reformasi birokrasi dalam pelayanan publik adalah peningkatan kualitas pelayanan, lebih cepat, lebih murah, lebih mudah, dan lebih berkualitas. Pada sektor kesehatan, rumah sakit milik Pemerintah Provinsi Jawa Tengah telah mengembangkan pelayanan berbasis elektronik. Tujuan penelitian ini adalah menggambarkan implementasi pelayanan berbasis teknologi informasi, identifikasi faktor pendukung dan penghambat, serta identifikasi kontribusi penggunaan teknologi informasi terhadap reformasi birokrasi. Penelitian ini bersifat deskriptif dengan pendekatan kualitatif. Subjek penelitian adalah 7 rumah sakit milik Pemerintah Provinsi Jawa Tengah. Adapun informan dalam penelitian ini adalah pengelola layanan rumah sakit serta pembuat aplikasi sistem. Teknik analisis data menggunakan model Miles dan Huberman yaitu pengumpulan, pengolahan dan penyajian data secara simultan. Kesimpulan penelitian ini adalah: 1) Pelayanan berbasis teknologi informasi berkembang sesuai dengan kapasitas dan sumberdaya masing-masing. Sistem yang dibangun secara mandiri lebih berkembang dan berlanjut, serta biaya rendah. 2) Faktor pendukung adalah budaya kerja yang baik, komitmen, edukasi, profesionalisme, tanggungjawab, egaliter, transparan, dan konstruktif. Hambatan internal berupa komitmen, kompetensi, dan sarana. Hambatan eksternal adalah aksesibilitas dan kurangnya pemahaman masyarakat. 3) Kontribusi pelayaan berbasis teknologi informasi adalah kecepatan pelayanan, kepastian waktu tunggu, transparansi, dan keadilan. Manfaat bagi rumah sakit meningkatkan efisiensi kerja, kecepatan dan kemudahan dalam memberikan pelayanan.
\end{abstract}

Kata kunci: reformasi birokrasi, pelayanan kesehatan, rumah sakit, Provinsi Jawa Tengah

\section{ABSTRACT}

One of the forms of bureaucratic reform in public services is to improve the quality of services, faster, cheaper, easier, and higher quality. In the health sector, hospitals owned by the Government of Central Java Province have developed electronic-based services. The purpose of this study is to describe the implementation of information technology-based services, identify supporting and inhibiting factors, and identify the contribution of information technology use to bureaucratic reform. This research is descriptive with a qualitative approach. Research subjects were 7 hospitals owned by the Government of Central Java Province. The informant is the manager of hospital services as well as the maker of the system application. Data analysis techniques using the model of Miles and Huberman, the collection, processing and presentation of data simultaneously. The conclusions of this study are: 1) Information technology-based services develop according to their capacities and resources Systems built independently are more developed and sustainable, and are low cost. 2) Supporting factors are good work culture, 
commitment, education, professionalism, responsibility, egalitarian, transparent and constructive. Internal barriers in the form of commitment, competence, and facilities. External barriers are accessibility and lack of public understanding. 3) The contribution of information technology-based services is speed of service, certainty of waiting time, transparency, and fairness. Benefits for hospitals improve work efficiency, speed and ease in providing services.

Keywords: bureaucratic reform, health services, hospitals, Central Java

\section{PENDAHULUAN}

Reformasi birokrasi yang terus bergulir memiliki tujuan meningkatkan penyelenggaraan pemerintahan, terutama pelayanan publik dalam rangka perbaikan kualitas kehidupan masyarakat. Reformasi birokrasi merupakan proses upaya sistematis, terpadu, komprehensif, ditujukan untuk merealisasikan tata pemerintahan yang baik/good governance (Sedarmayanti, 2009). Upaya reformasi birokrasi dilakukan melalui perubahan mengarah pada pemerintahan yang lebih baik sesuai dengan kebutuhan masyarakat dan dinamika kemajuan zaman. Hal ini penting karena dinamika perubahan harus disikapi dengan baik agar tercipta tertib bernegara dan bermasyarakat, dimana tugas birokrasi adalah menjalankan kewajiban negara kepada rakyatnya. Tata Kelola Pemerintahan yang baik atau Good Governance merupakan proses penyelenggaraan birokrasi dalam pelayanan barang dan jasa publik berdasarkan prinsip efektifitas, keadilan, partisipasi, akuntabilitas, dan transparansi (Akhmaddhian, 2012). Selain itu juga mengacu pada paradigma New Public Services yaitu pemerintah sebagai pelayan, melayani bukan mengarahkan, tidak dijalankan dengan prinsip bisnis (Denhardt \& Denhardt, 2007).

Secara nasional sesuai Grand Design Reformasi Birokrasi 2010-2025 (Peraturan Presiden Nomor 81 Tahun 2010) terdapat delapan area perubahan yang ditetapkan, yaitu: 1) manajemen perubahan; 2) penataan peraturan perundang-undangan;
3) penataan dan penguatan organisasi; 4) penataan tatalaksana; 5) penataan sistem manajemen sumber daya manusia aparatur; 6) penguatan pengawasan; 7) penguatan akuntabilitas kinerja; dan 8) peningkatan kualitas pelayanan publik.

Pelayanan publik merupakan sektor yang mendapat banyak perhatian. Salahsatu sektor wujud nyata reformasi birokrasi dalam pelayanan publik adalah mempersingkat waktu pelayanan (Akhmaddhian, 2012). Di dalam pelayanan publik, prosedur dan aturan yang jelas sangat diperlukan agar pelayanan tidak menemui kendala (Yusriadi dan Misnawati, 2017). Reformasi birokrasi berpengaruh signifikan terhadap kualitas pelayanan yaitu perubahan cara berpikir (mindset) pegawai dari penguasa menjadi pelayan, dan meningkatkan pengawasan masyarakat terhadap kinerja birokrasi. Kecepatan birokrasi dalam pelayanan dengan memangkas regulasi, peraturan, maupun sistem yang menghambat, serta penggunaan sistem yang lebih tanggap merupakan salahsatu ciri keberhasilan reformasi birokrasi (Taufan, 2017).

Hasil penelitian Nurbarani (2009) di Kota Surakarta menemukan bahwa keberhasilan reformasi birokrasi didorong oleh program inovatif yang bertujuan untuk memenuhi kebutuhan masyarakat, serta adanya prinsip-prinsip utama yang melandasi pelaksanaan good governance. Inovasi dipandang sebagai kebutuhan karena dapat mengatasi masalah patologi birokrasi, meningkatkan kualitas pelayanan publik, memaksimalkan potensi 
aparatur, serta mengembalikan kepercayaan publik (Andhika, 2017).

Saat ini mulai tumbuh dengan apa yang disebut electronic government (eGov) sebagai implementasi penggunaan teknologi informasi dan komunikasi dalam pemerintahan. Bank Dunia mendefinisikan electronic government (e-gov) sebagai upaya penggunaan teknologi informasi oleh lembaga pemerintah (Indrajit, 2009 \& Samodra Wibawa, 2009). Banyak kegiatan pelayanan publik yang dapat disediakan melalui elektronik (Holle, 2011). Reformasi birokrasi dituntut memberikan konstribusi positif terhadap kecepatan pelayanan dan peningkatan daya saing bangsa (Cahyono, 2017).

Salahsatu area reformasi birokrasi adalah pelayanan publik. Pelayanan publik merupakan serangkaian aktivitas yang dilakukan oleh birokrasi publik untuk memenuhi kebutuhan warga negara (Agus Dwiyanto, 2005). Birokrasi dituntut memberikan layanan yang berkualitas dan cepat (Eddy Cahyono, 2017). Tujuan pelayanan publik pada dasarnya adalah memuaskan masyarakat, untuk itu dituntut kualitas pelayanan prima yang tercermin dari: 1) transparansi, 2) akuntabilitas, 3) efisiensi dan efektifitas, 4) partisipatif, 5) kesamaan hak, 6) keseimbangan hak dan kewajiban (Sinambela dalam Nuril, 2018).

Beberapa jenis atau ruang lingkup pelayanan publik sesuai ketentuan Undang-undang No. 25 Tahun 20019 tentang Pelayanan Publik, pasal 5 meliputi: 1) pelayanan barang publik dan jasa publik, serta 2) pelayanan administratif yang diatur dalam peraturan perundang-undangan. Sesuai dengan ketentuan pasal 12 Undang-undang Nomor 23 Tahun 2014 tentang Pemerintahan Daerah, bahwa kesehatan merupakan salahsatu bentuk pelayanan dasar yang wajib dilaksanakan oleh pemerintah daerah. Sesuai dengan Undang-Undang Nomor 36 Tahun 2009 tentang Kesehatan, disebutkan bahwa "Setiap orang mempunyai hak yang sama dalam memperoleh akses atas sumber daya di bidang kesehatan". Pemerintah bertanggungjawab atas ketersediaan lingkungan, tatanan, fasilitas kesehatan baik fisik maupun sosial, ketersediaan sumber daya, ketersediaan akses terhadap informasi, edukasi, dan fasilitas pelayanan kesehatan.

Komitmen Pemerintah Provinsi Jawa Tengah mewujudkan reformasi birokrasi tertuang dalam pernyataan misi "Mempercepat reformasi birokrasi yang dinamis serta memperluas sasaran ke pemerintahan Kabupaten/Kota". Reformasi birokrasi dilakukan dalam tiga dimensi utama yaitu: 1) pelayanan publik yang semakin dinamis, 2) efektivitas dan efisiensi manajemen pemerintahan, 3) kapasitas kelembagaan dan manajemen sumber daya manusia aparatur yang semakin baik. Pelayanan publik yang dinamis diimplementasikan dalam kerangka membangun open government dan pemerintahan yang responsif. Open government diwujudkan melalui keterbukaan informasi publik, transparansi, partisipasi publik dalam penyelenggaraan pemerintahan, serta meningkatkan komunikasi dan serapan aspirasi publik. Pemerintahan yang responsif berupa kecepatan dalam menyikapi aduan dan persoalan riil masyarakat. Pelayanan publik yang dinamis memiliki prinsip pelayanan yang mudah, murah, cepat, serta didukung inovasi dan teknologi informasi.

Terdapat 4 (empat) strategi utama yaitu: 1) meningkatkan pelayanan publik langsung kepada masyarakat; 2) meningkatkan pemanfaatan dan perkembangan teknologi informasi dalam birokrasi; 3) meningkatkan manajemen pemerintahan yang bersih dan akuntabel; 4) mewujudkan sistem manajemen sumber daya aparatur yang baik dan efisiensi kelembagaannya. Pelayanan publik 
bertumpu pada dua strategi utama yaitu direct services dan digitalisasi tata kelola pemerintahan. Direct services dilakukan melalui road show dan "jemput bola" sebagai upaya perwujudan open government dimana terdapat keterbukaan informasi publik, transparansi, partisipasi publik, komunikasi dan serapan aspirasi publik. Adapun digitalisasi pemerintahan dilakukan melalui pengembangan jaringan infrastruktur teknologi informasi, pengelolaan sistem informasi pemerintah berbasis elektronik (e-government) dan meningkatkan kemampuan ASN dalam penggunaannya.

Pada sektor kesehatan, beberapa rumah sakit milik Pemerintah Provinsi Jawa Tengah juga telah mengembangkan pelayanan berbasis elektronik. Pemerintah Provinsi Jawa Tengah memiliki 7 (tujuh) Rumah Sakit Daerah yaitu RSJD Dr. RM. Soedjarwadi Klaten, RSJD Dr. Amino Gondohutomo Semarang, RSJD Surakarta, RSUD Dr. Moewardi Surakarta, RSUD Kelet Jepara, RSUD Prof. Dr. Margono Soekarjo Purwokerto, RSUD Tugurejo Semarang. Semua rumah sakit milik Pemerintah Provinsi Jawa Tengah tersebut telah mengembangkan sistem layanan berbasis elektronik. Layanan elektronik yang terdapat di semua rumah sakit adalah pendaftaran pasien, serta open data. Sebagian rumah sakit bahkan telah mengembangkan layanan dalam bentuk aplikasi dalam perangkat android. Beberapa rumah sakit menerapkan sistem pendaftaran elektronik sebagai prosedur utama. Kondisi tersebut cukup menarik sebagai salahsatu wujud reformasi birokrasi dalam pelayanan kesehatan sesuai dengan perkembangan teknologi informasi.

Meskipun belum terdapat pengukuran khusus terhadap implementasi layanan tersebut, secara umum indeks kepuasan masyarakat terhadap layanan Pemerintah Provinsi Jawa Tengah naik dari 73,01 di tahun 2014 menjadi 79,17 di tahun 2018. Indeks Sistem Pemerintahan Berbasis Elektronik (SPBE) Jawa Tengah pada tahun 2018 sebesar 3,68 , dimana capaian ini melebihi target yang ditetapkan RPJMD 2018-2023. Di sisi lain Indeks Reformasi Birokrasi tahun 2017 sebesar 76,53 dan turun pada tahun 2018 menjadi 74,49. Penurunan ini tentunya perlu menjadi perhatian dimana seharusnya penggunaan teknologi informasi tentunya diperuntukkan dalam rangka reformasi pelayanan publik untuk kemudahan. Hasil penelitian Rizki (2019) tentang Reservasi Online Support System (ROSS) bahwa penerapan pendaftaran online belum menunjukan keunggulan jika tidak ada pemangkasan birokrasi dan penyederhanaan SOP. Keunggulan yang belum muncul tersebut mengakibatkan dampak yang ditimbulkan oleh inovasi ini belum terasa (Rizki, 2019).

Penggunaan teknologi informasi dalam pelayanan publik ditujukan untuk meningkatkan efisiensi pelayanan. Sebagaimana dinyatakan Indrajit (2009) bahwa manfaat nyata dirasakan Amerika dan Inggris dari e-government diantaranya memperbaiki kualitas pelayanan, serta mengurangi biaya administrasi, relasi, dan interaksi. Penelitian Adrizal, dkk, (2019) menunjukkan bahwa penggunaan teknologi informasi meningkatkan kepuasan, ketepatan, serta kualitas pelayanan. Dukungan kebijakan dan sarana prasarana dibutuhkan agar kualitas pelayanan dapat ditingkatkan. Penelitian Nabyla dan Hariyono (2019) menunjukkan bahwa sistem pendaftaran online berbasis smartphone pada layanan kesehatan memberikan kemudahan bagi pasien terutama dalam mendaftar dan antrian. Hasil penelitian lainnya juga menunjukkan bahwa salahsatu faktor yang mempengaruhi tingkat kepuasan pasien terhadap sistem rujukan online di fasilitas kesehatan adalah kepahaman atas sistem 
rujukan online sendiri (Muchsam \& Mareta, 2019). Faktor pendukung pendaftaran online adalah koordinasi, dukungan teknologi dan informasi, serta penyediaan fasilitas, adapun faktor penghambatnya adalah keterbatasaan pengetahuan masyarakat, sumber daya manusia pelaksana inovasi, dan sistem layanan (Rizki, 2019).

Berdasarkan penjelasan di atas penting untuk mengetahui implementasi pemanfaatan teknologi informasi pada rumah sakit milik Pemerintah Provinsi Jawa Tengah serta kontribusinya terhadap reformasi birokrasi. Dibutuhkan kajian untuk mengetahui bagaimana pelayanan kesehatan pada rumah sakit milik Pemerintah Provinsi Jawa Tengah melalui teknologi informasi menunjukkan suatu upaya refomasi birokrasi. Oleh karena itu, permasalahan yang perlu dikaji adalah bagaimana rumah sakit milik Pemerintah Provinsi mengembangkan inovasi, apa saja faktor kunci keberhasilanya, serta dampaknya terhadap pelayanan kepada masyarakat. Penelitian ini bertujuan untuk memberikan informasi terkait implementasi layanan berbasis teknologi informasi di rumah sakit, identifikasi faktor pendukung dan penghambat, serta dampaknya terhadap reformasi birokrasi, khususnya pelayanan publik.

\section{METODE PENELITIAN}

Penelitian ini merupakan penelitian deskriptif dengan pendekatan kualitatif. Menurut Arikunto (2002) penelitian deskriptif untuk mengetahui keadaan sesuatu mengenai apa dan bagaimana, berapa banyak, sejauh mana dan sebagainya. Penelitian kualitatif menurut Usman dan Purnomo (2008) berusaha memahami dan menafsirkan makna suatu peristiwa interaksi tingkah laku manusia dalam situasi tertentu menurut perspektif peneliti sendiri. Penelitian ini bersifat terapan yaitu usaha menjawab masalah dengan tujuan praktis dan jelas (Daniel, dkk, 2005). Subjek penelitian ialah para penyelenggara pelayanan di 7 rumah sakit milik Pemerintah Provinsi Jawa Tengah. Informan yang terlibat dalam penelitian ini adalah para pengelola layanan rumah sakit serta pembuat aplikasi sistem. Instrumen yang digunakan dalam penelitian ini ialah panduan wawancara atau daftar pertanyaan terbuka untuk mengumpulkan data primer dari para pelaku. Instrumen lain adalah peralatan perekam data elektornik. Data sekunder diperoleh dari website masing-masing rumah sakit. Teknik analisis data menggunakan model simultan sesuai konsep Miles dan Huberman, yaitu proses pengumpulan, pengolahan dan penyajian data secara simultan dalam rangka menghasilkan kesimpulan yang saling terkait (Usman dan Purnomo, 2008). Konsep Miles dan Huberman menggunakan tiga langkah utama yaitu reduksi data untuk mempermudah peneliti menajamkan analisis, penyajian data yang baik membantu peneliti menganalisis untuk mengarahkan pada kesimpulan, dan penarikan kesimpulan/verifikasi sebagai suatu penggambaran makna yang utuh setalah melalui pengujian atau verifikasi.

\section{HASIL DAN PEMBAHASAN Hasil}

Seluruh Rumah Sakit milik Pemerintah Provinsi Jawa Tengah telah mengembangkan sistem layanan berbasis elektronik. Layanan elektronik yang terdapat di semua rumah sakit tersebut memiliki sejarah dan metode yang berbeda-beda. Setiap rumah sakit menggunakan media, aplikasi dan bahasa pemorgraman yang berbeda. Secara umum layanan tersebut diberikan untuk proses pendaftaran pasien, informasi jadwal layanan, serta administrasi. Sebagian rumah sakit telah mengembangkan layanan dalam bentuk website serta 
sebagian juga dilengkapi dengan aplikasi android, dan menerapkan sistem pendaftaran elektronik sebagai metode utamanya.

\section{1) RSJD Dr. RM. Soedjarwadi Klaten}

Rumah Sakit Jiwa Daerah (RSJD)

Dr. RM. Soedjarwadi Klaten telah mengembangkan pelayanan eksternal melalui aplikasi pendaftaran online yang bisa di-install dalam perangkat berbasis android. Melalui aplikasi ini, masyarakat bisa melakukan pendaftaran secara online, memilih klinik dan dokter, jadwal kunjungan dokter, informasi resep. Masyarakat bisa mengetahui informasi antrian poliklinik, ketersediaan tempat tidur, informasi layanan, informasi publik dan layanan data lainnya. Masyarakat juga bisa memberikan masukan atau pengaduan kepada manajemen rumah sakit.

Secara internal juga telah dikembangkan aplikasi manajemen rumah sakit dalam bentuk SIM - RS (Sistem Informasi Manajemen Rumah Sakit). Menurut C. Adi $\mathrm{P}$ selaku tim pengguna sistem, manfaat penggunaan aplikasi tersebut adalah mempercepat proses untuk pelayanan dan operasional rumah sakit. Dengan aplikasi tersebut proses bisnis rumah sakit menjadi lebih cepat, tersedianya informasi untuk manajemen, serta efisiensi tenaga atau pengurangan SDM pada suatu proses. Dengan layananlayanan tersebut, proses bisnis rumah sakit dan pelayanan berjalan dengan lebih cepat dan efisien. Masyarakat juga merasakan manfaat, selain itu mereka juga berpartisipasi dalam perbaikan dengan memberikan saran masukan dan aduan. Berdasarkan masukan masyarakat tersebut, rumah sakit memiliki bahanbahan informasi untuk perbaikan.

Adapun beberapa hambatan yang dialami adalah adanya kebijakan dan keterkaitan dengan sistem lain. Beberapa regulasi dari luar rumah sakit yang menghambat pemanfaatan dari suatu layanan. Contohnya ketentuan mengenai rujukan berjenjang dari BPJS cukup menghambat kecepatan pelayanan rumah sakit. Adapun terkait dengan sistem lain adalah adanya perubahan-perubahan dari sistem lain dengan cepat, misalnya sistem aplikasi BPJS yang berubah sehingga pihak rumah sakit juga harus menyesuaikan.

\section{2) RSJD Dr. Amino Gondohutomo Semarang}

Rumah Sakit Jiwa Daerah (RSJD)

Dr. Amino Gondohutomo Semarang tergolong memiliki saluran yang lebih terbatas dibanding rumah sakit milik Pemerintah Provinsi Jawa Tengah lainnya. Layanan melalui website berupa PPID dan open data sudah tersedia. Begitu juga dengan informasi ketersediaan ruang rawat inap juga sudah terpampang di website. Hanya saja layanan pendaftaran yang disediakan masih menggunakan SMS center. Hal ini berbeda dengan layanan di rumah sakit lainnya yang sudah menggunakan aplikasi android atau layanan website.

\section{3) RSJD Surakarta}

Layanan pada Rumah Sakit Jiwa Daerah (RSJD) dr Arif Zainudin Surakarta sebagaimana yang disampaikan Totok Hardiyanto selaku pengguna aplikasi ada banyak aplikasi (53 aplikasi) yang digunakan baik dari internal maupun eksternal. Dari eksternal ada berbagai aplikasi baik dari pemerintah pusat maupun Pemerintah Provinsi (GRMS, open data, PPID). Adapun dari internal telah dikembangkan aplikasi pendaftaran online, PPID, serta Wilayah Bebas Korupsi (WBK) berbasis android. SPOL AZ (sistem pendaftaran online dr Arif Zainudin) dikembangkan untuk memudahkan pasien/keluarga pasien melakukan pendaftaran dan mengakses jadwal dokter, poliklinik, informasiinformasi penting lainnya. Aplikasi ini 
tersedia dalam format website maupun android.

Pihak RSJD Surakarta juga mengembangkan aplikasi PPID berbasis android. Melalui aplikasi ini masyarakat dapat meminta pelayanan data dan informasi yang dibutuhkan terkait dengan pelayanan atau data-data lainnya tentang rumah sakit. Dalam rangka meningkatkan integritas institusi, RSJD Surakarta juga mengembangkan aplikasi Griya WBK. Aplikasi ini berfungsi untuk menyampaikan kepada publik tentang integritas lembaga dalam memerangi korupsi. Aplikasi ini berisi informasi laporan kinerja dari setiap kelompok kerja atau pokja yang ada di RSJD Surakarta.

Manfaat penggunaan aplikasi tersebut menurut Totok Hardiyanto (pengguna aplikasi) adalah mempermudah proses kerja, mempermudah pengguna baik masyarakat maupun manajemen rumah sakit, serta meningkatnya kepercayaan publik. Perubahan yang terjadi setelah penggunaan aplikasiaplikasi tersebut yang dirasakan adalah proses kerja menjadi lebih singkat, tahaptahap pekerjaan menjadi jelas, serta adanya perubahan lain seperti mental aparat dan budaya kerja. Selain itu, kepercayaan publik juga meningkat yang dibuktikan dengan menurunnya komplain. Dengan diperkenalkannya metode online ini, masyarakat juga sangat dimudahkan sehingga tingkat kepuasan meningkat.

Hambatan yang terjadi dari implementasi aplikasi tersebut adalah terkait dengan pelayanan kesehatan itu sendiri dan ketersediaan SDM. Layanan teknologi informasi adalah penunjang dari layanan sesungguhnya yaitu kesehatan. Ketika layanan kesehatan dirasakan tidak berkualitas atau dipersulit maka keluhan dan aduan akan masuk melalui saluran ini. Terjadinya kesenjangan antara konsep pelayanan model lama dan pelayanan saat ini menjadi salah satu penghambat.
Penghambat lain adalah SDM yang kurang kompeten, terutama generasi terdahulu. Selain itu, ketersediaan SDM yang memahami teknologi informasi juga menjadi hambatan tersendiri. Ancaman dari keberlangsungan sistem ini adalah pergantian pimpinan bisa jadi adanya pergantian kebijakan, termasuk terkait penggunaan aplikasi ini. Adapun dari aspek teknis ialah masih rentannya aplikasi, dimana server sering down sehingga menghambat pelayanan online. Pada konteks dan kasus ini rumah sakit memiliki keterbatasan terkait dengan infrastruktur teknologi.

\section{4) RSUD Dr. Moewardi Surakarta}

Rumah Sakit Umum Daerah (RSUD) Dr. Moewardi Surakarta adalah salah satu rumah sakit terdepan dalam implementasi layanan berbasis teknologi informasi ini. Sesuai informasi Aris dan Gugun (tim PDE), mereka saat ini memiliki 3 layanan utama, yaitu terkait dengan pasien, dokter, dan manajemen. Aplikasi tersebut dikembangkan oleh tenaga internal yang merupakan divisi khusus menangani teknologi informasi termasuk pengembangan aplikasi.

Pada awalnya mereka bekerjasama dengan pihak ketiga (developer) di tahun 2012 - 2014 dengan dana sekitar 3 milyar rupiah. Namun setelah selesai kontrak tahun 2014 sistem tidak lagi dijalankan. Setelah itu diputuskan untuk membangun sendiri sistem aplikasinya dengan memanfaatkan infrastruktur yang ada (server sendiri). Pembangunan aplikasiaplikasi tersebut tidak terlepas dari peran penting seorang dokter spesialis penyakit dalam (dr. R. Satrio Budi S., Sp.PD) yang memiliki kemampuan di bidang teknologi informasi. Aplikasi yang dikembangkan berbasis pada prinsip sistem electronic medical record. Dengan peran SDM internal tersebut, pembangunan aplikasi tidak membutuhkan banyak biaya. Adapun aspek infrastruktur sudah memiliki server 
yang dibeli terbaru tahun 2018 dengan spesifikasi AP Pro link generasi 9 memory 365 Giga, double processor. Infrastruktur pendukungnya adalah jaringan fiber optic lintas gedung.

Adapun 3 aplikasi yang saat ini efekif digunakan, yaitu e-patient, e-doctor, dan e-employee. E-patient merupakan aplikasi yang digunakan rumah sakit untuk berhubungan dengan pasien. E-patient menyediakan layanan pendaftaran, infomasi jadwal dokter, informasi antrian daftar, nomor antrian, informasi dokter, proses farmasi, pengaduan dan beberapa informasi lainya. Aplikasi e-doctor digunakan untuk berhubungan dengan dokter. Melalui aplikasi ini manajemen memberikan informasi kepada dokter jumlah pasien, jasa pelayanan, absensi internal. Dokter juga mendapatkan notifikasi saat operasi, order operasi, ada pemetaan jadwal untuk dokter, jadwal visit dokter, rincian jasa pelayanan dan lain sebagainya. Dokter juga mendapatkan notifikasi jumlah pasien hari itu yang akan mengunakan jasanya.

Aplikasi e-employee merupakan penghubung antara manajemen dan karyawan. Melalui e-employee, karyawan dapat melihat jasa pelayanan, absensi, bahkan sampai order mobil dinas. Semua aplikasi tersebut sudah bisa diterapkan untuk perangkat berbasis andorid, tetapi masih ditolak pada sistem apple.
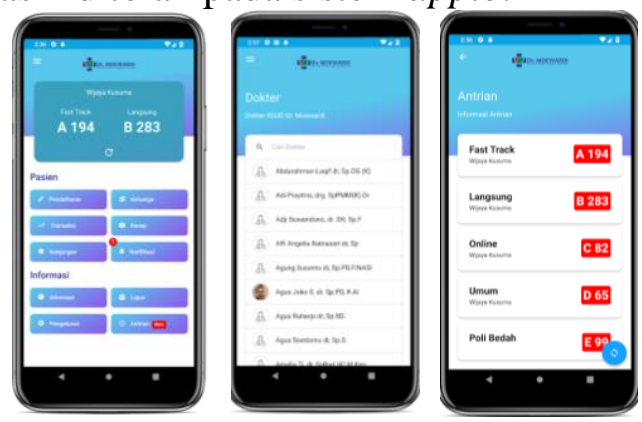

Gambar 1.

Tampilan Informasi Pasien RSDM

Surakarta
Terobosan lainnya adalah berkolaborasi dengan BPJS Kesehatan membangun aplikasi electronic claim, yaitu proses klaim biaya layanan ke BPJS Kesehatan. Pihak rumah sakit tidak perlu lagi menyetorkan berkas kertas yang sangat banyak untuk mengklaim biaya layanan pasien. Klaim cukup dilakukan melalui aplikasi ini dimana data-data yang dibutuhkan sudah tersedia semua. Datadata pasien yang dirawat juga diakses melalui data BPJS. Aplikasi ini tergolong masih sangat baru, merupakan pelopor si kawasan Solo Raya.

Sistem ini diterapkan efektif sejak tahun 2017 yang langsung dimanfaatkan oleh 500 pendaftar. Saat ini, semua pendaftaran harus masuk melalui sistem online, tidak ada lagi proses manual. Meskipun pasien datang ke rumah sakit tanpa melakukan pendaftaran online, mereka bisa melakukan pendaftaran online di tempat, atau melakukan pendaftaran langsung namun kemudian oleh petugas akan dimasukkan dalam sistem online. Dengan demikian tidak ada lagi sistem pendaftaran manual, semua harus masuk sistem minimal dengan bridging dan dibantu petugas di loket pendaftaran. Semua data pendaftaran telah diproses melalui teknologi informasi.

Pendaftaran di RSUD Moewardi terbagi menjadi 3 jenis, yaitu online, langsung, dan on site. Sistem pendaftaran online berlaku di semua poliklinik, pendaftaran on site untuk paviliun cendana, geriatri, pediatri dan obsgin. Pendaftaran langsung dilakukan melalui "Apem Gerobag", yaitu fasilitas pendaftaran langsung (manual) di loket pendaftaran rumah sakit. Pendaftaran online bisa dilakukan paling lambat sehari sebelumnya, sedangkan pendaftaran yang dilakukan pada hari bersangkutan datang menggunakan pendaftaran langsung atau on site. Pendaftaran on site adalah pasien datang kemudian menggunakan perangkat 
/anjungan yang telah disediakan untuk melakukan pendaftaran yang masuk dalam sistem online. Pasien mengambil nomor antrean, kemudian mendaftar dengan barcode, langsung cetak dan ke anjungan. Pasien juga bisa langsung mendaftar di loket, kemudian akan dimasukkan juga dalam sistem online dengan sistem bridging. Aplikasi android sendiri bisa digunakan lebih dari satu orang, sehingga satu akun bisa digunakan untuk seluruh anggota keluarga.

Kesulitan atau komplain masyarakat relatif tidak ada. Pada awalnya pendaftaran menggunakan nomor rujukan, namun beberapa kali terjadi kesalahan meng-input nomor rujukan, sehingga kemudian diganti nomor BPJS. Beberapa pasien juga kadang kesulitan menemukan fitur-fitur dalam layanan android, oleh sebab itu kemudian tata letak diubah agar mudah terlihat. Pasien atau keluarga pasien akan meng-input nomor BPJS untuk mengakses layanan. $\mathrm{Di}$ dalam aplikasi tersebut semua data pasien sudah tersedia di dalam akun yang bersangkutan. Pendaftaran online ini bisa dilakukan mulai dari sebulan sebelum rencana kunjungan sampai sehari sebelum berkunjung. Selain tersedia dalam format android, pendaftaran online juga bisa dilakukan melalui website. Prosedur pendaftaran juga sama persis sebagaimana dalam aplikasi android. Melalui aplikasi ini pasien dapat memantau semua proses, mulai dari antrian pendaftaran, jadwal dokter, sampai dengan farmasi, yang mana akan ada notifikasi dari farmasi jika obat sudah siap diberikan.

Pendaftaran online bisa dilakukan jika pasien sudah terdata atau sudah pernah berkunjung sebelumnya. Untuk pasien baru maka harus mendaftar melalui formulir pendaftaran. Bagian pelayanan bertugas meng-input data pasien, baik yang lama maupun yang baru.
Aplikasi lainnya adalah sistem informasi pengaduan terintegrasi "Singa Teriak", yaitu portal aduan masyarakat. Pengaduan masyarakat melalui "Singa Teriak" akan masuk ke humas, kemudian akan diteruskan ke e-employee untuk didistribusi sesuai tugasnya.

Beberapa hal yang perlu ditingkatkan antara lain kelengkapan data dan layanan penunjang. Data-data profil dokter masih sangat jarang karena data diisi sendiri profilnya, sementara banyak dokter yang belum sempat mengisi. Demikian juga dengan layanan penunjang belum masuk sistem, dimana pasien yang harus ditindaklanjuti layanan penunjang belum bisa melalui proses online, namun daftarnya sudah ada di aplikasi. Dari aspek dokumen masih digunakan kertas karena klaim BPJS harus ada cetak pendaftaran, selain dokumen elektronik.

Beberapa hal yang sudah
diperbaiki adalah terkait dengan pengelolaan SDM, dimana tunjangan tenaga pengelola ditingkatkan, berbeda dengan pegawai divisi lainnya. Tenaga pengelola direkrut sesuai kompetensi, dimana berbasis TI dan analisa sistem. Terkait dengan pengembangan sistem juga sudah dibentuk group sharing diantara para pengelola teknologi informasi rumah sakit, baik tingkat Solo Raya maupun Jawa Tengah.

\section{5) RSUD Kelet Jepara}

Rumah Sakit Umum Daerah (RSUD) Kelet Jepara menggunakan aplikasi SIMRS, SIDIO, SIPAS, Pendaftaran online, e-rengger, simpeg, dan SIRDK. Sebagian aplikasi tersebut merupakan aplikasi eksternal dan sebagian lagi dikembangkan sendiri untuk keperluan pelayanan. Aplikasi tersebut tersedia dalam bentuk website maupun aplikasi android. Aplikasi pendaftaran online dikembangkan untuk memudahkan pasien melakukan pendaftaran. Pasien 
dapat melihat jadwal poliklinik, jadwal dokter, dan pasien memilih sendiri mau kemana berkunjung. Sistem pendaftaran online ini juga melayani pasien dari poliklinik ke farmasi sampai kasir.

Masyarakat bisa mengakses informasi publik melalui portal "SI PUTRI" (Sistem Informasi Pelayanan Publik Terintegrasi). Melalui portal ini, masyarakat bisa meminta pelayanan informasi terkait dengan pelayanan RSUD Kelet Jepara. Selain informasi publik, masyarakat juga bisa mengajukan usulan kegiatan terhadap RSUD Kelet, Jepara. Melalui e-renggar masyarakat diberi ruang untuk mengusulkan kegiatan seuai dengan kebutuhan mereka.

Menurut Achmad MA dan Catur selaku pengguna sistem, manfaat yang dirasakan langsung dari penggunaan aplikasi ini adalah memudahkan bagi pasien untuk berobat, mulai dari pendaftaran sampai instalasi farmasi. Bagi rumah sakit sistem ini meningkatkan efisiensi kerja, meningkatkan kecepatan dan kemudahan dalam memberikan pelayanan. Serangkaian perubahan penting terjadi di dalam pelayanan, antara lain waktu tunggu pasien yang menjadi lebih singkat mulai pendaftaran sampai bertemu dokter, informasi penting bisa cepat diketahui masyarakat misalnya ketersediaan kamar. Rumah sakit juga mudah mendapatkan masukan dari masyarakat, baik keluhan, aduan atau usulan kegiatan. Pengembangan pelayanan RSUD Kelet Jepara menjadi bisa terarah dengan adanya masukan dari masyarakat. Sedangkan beberapa kendala yang masih dialami antara lain terkait dengan pemahaman pengguna. Sebagian masyarakat masih sering salah alur pendaftaran ketika menggunakan media online ini. Hal ini juga disebabkan karena minimnya sosialisasi aturan dalam pendaftaran online itu sendiri.

\section{6) RSUD Prof. Dr. Margono Soekarjo Purwokerto}

Rumah Sakit Umum Daerah (RSUD) Prof. Dr. Margono Soekarjo Purwokerto sudah memiliki kemajuan tersendiri, bahkan prestasinya diakui di tingkat nasional. Rumah sakit ini merupakan pelopor inovasi manajemen rumah sakit berbasis teknologi informasi di Jawa Tengah, bahkan beberapa kali mendapat penghargaan di tingkat nasional. Sesuai dengan penyampaian Ragil Purnomo, SE dan Utami (bagian perencanaan), aplikasi unggulan yang sudah digunakan saat ini adalah RSMS Online, Tele Apik, Sibina Cantik dan Open Data. Dari aplikasi tersebut dapat dilakukan layanan rumah sakit online, registrasi online, informasi kepada pasien, dan kepada masyarakat luas.

Pada tahun 2017 RSUD Margono mendapatkan penghargaan inovasi pelayanan publik (Sinovik) dari Kementerian PAN dan RB, yaitu untuk "SI BINA CANTIK" (Sistem Bridging SIM RSMS, BPJS, dan INA-CBG's menuju akuntabilitas, transparansi, dan efisiensi pelayanan kesehatan JKN secara paripurna). Layanan yang dikembangkan mulai tahun 2014 sampai 2016 tersebut berupa pelayanan terintegrasi dari pendaftaran hingga pengambilan obat dan klaim pembayaran, terutama untuk pelayanan JKN. "SI BINA CANTIK" merupakan pelopor integrasi atau bridging data antara rumah sakit dengan BPJS Kesehatan di Indonesia. Bridging data ini membawa terobosan besar pada mekanisme klaim biaya rawat pasien dengan pihak BPJS. Bridging dilakukan dengan data BPJS Kesehatan dan INACBGs yang merupakan ketentuan standar biaya perawatan berdasarkan sistem "paket" yang ditetapkan Kementerian Kesehatan. Integrasi dengan kedua data tersebut memungkinkan rumah sakit mengetahui perkiraan biaya perawatan 
berdasarkan diagnosis, serta perkiraan biaya yang ditanggung BPJS Kesehatan dan besaran iur biaya pasien. Terobosan ini merupakan yang pertama di Indonesia.

Pengembangan lebih lanjut dari sistem aplikasi ini adalah electronic validation ( $\mathrm{E}$ - val). RSUD Margono sedang mengembangkan sistem validasi terhadap tagihan biaya pelayanan pasien kepada BPJS Kesehatan, bermula dari ditariknya pegawai BPJS Kesehatan yang bertugas memvalidasi berkas di rumah sakit, maka pihak rumah sakit harus melakukan validasi di kantor. Oleh karena cukup menyita waktu dan tenaga, maka dibangun sistem yang memudahkan validasi tersebut dengan aplikasi. Saat ini aplikasi $e$ val yang sedang dikembangkan tersebut masuk dalam tahap uji coba bekerjasama dengan BPJS Kesehatan (pusat). Uji coba ini merupakan pilot project untuk pematangan $e$ val agar bisa diaplikasikan secara nasional.

Aplikasi RSMS online atau pendaftaran online sudah dirintis sejak beberapa tahun terakhir. Layanan ini mulai dikembangkan tahun 2014, dan sampai dengan tahun 2019 pengguna pendaftaran online sebesar 87 persen. Hal ini menandakan bahwa sistem pendaftaran online sudah diterima dengan baik oleh masyarakat. Sebelumnya, pendaftaran juga dilakukan melalui sistem PENETRASI ONLINE (Pengembangan Sistem Short Message Service Gateway Menuju Registrasi Online). Layanan ini menggunakan SMS gateway sebagai sarana pendaftaran pasien. Sistem ini juga mendapatkan penghargaan, meskipun saat ini lebih banyak pasien yang mendaftar menggunakan aplikasi android.

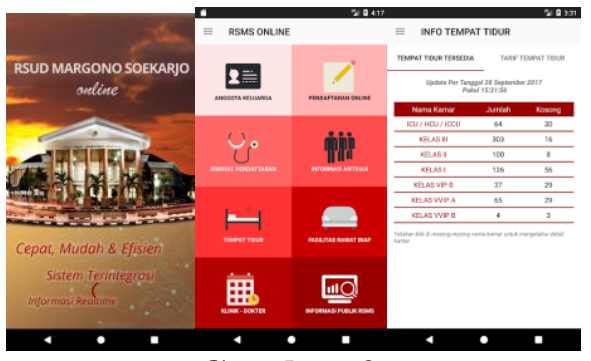

Gambar 2.

Tampilan RSMS Online

Aplikasi berikutnya adalah "Tele Apik" (Teyeng Ndeleng Antrian Pendaftaran lan Poliklinik), yaitu berupa informasi tentang antrian pendaftaran dan antrian di poliklinik. "Tele Apik" sebagaimana dikemukakan Utami, adalah pengembangan lebih lanjut dari pendaftaran online, yang sudah diintegrasikan dengan data rekam medik, jadwal dokter dan poliklinik, serta layanan penunjang lainnya. "Tele Apik" menggunakan perangkat android yang harus diinstall, sehingga akan keluar akun. Satu akun bisa digunakan oleh beberapa orang, sehingga bisa digunakan untuk satu keluarga atau membantu orang yang tidak bisa mengoperasikan pendaftaran online.

Pasien yang sudah mendaftar online, akan mendapatkan kode booking dan barcode, kemudian akan diproses/ di scan di loket pendaftaran, dan akan mendapatkan nomor antrian pelayanan dan informasi mengenai perkiraan jam pelayanan. Dengan informasi ini pasien bisa menggunakan waktu berkunjung dengan efisien, serta bisa memperkirakan jadwal pelayanan. Pasien bisa mendaftarkan diri pada $\mathrm{H}-7$ sebelum berkunjung.

Pada antrian pendaftaran, masyarakat bisa melihat antrian nomor pendaftaran yang sudah dipanggil berdasarkan jenis pendaftar. Informasi antrian di poliklinik juga bisa dilihat untuk setiap poliklinik, bisa dilihat jumlah pasien yang terdaftar dan jumlah pasien yang sudah dilayani. Pada antrian poliklinik, 
pasien akan mendapatkan nomor antrian dan perkiraan jam pelayanan.

Untuk masyarakat yang belum menggunakan perangkat android, disediakan loket pendaftaran manual. Tersedia sebanyak 17 loket pendaftaran yang melayani masyarakat. Selain itu disediakan juga tenaga pembantu / helper bagi masyarakat yang kesulitan mengakses apliksi atau melakukan pendaftaran online. Petugas tersebut juga akan membantu instalasi aplikasi ke perangkat android jika pasien menemui kesulitan.

Manfaat langsung dari penggunaan aplikasi tersebut adalah adanya kecepatan pelayanan, kepastian waktu tunggu, transparansi, dan keadilan. Penggunaan aplikasi juga berpengaruh pada kinerja, diantaranya menjamin dokter datang tepat waktu jam 08.00 (disiplin) dan tahu berapa jumlah pasien hari itu, meningkatkan kepuasan pasien, serta mengurangi waktu antrian. Tentunya untuk mencapai perubahan tersebut diperlukan komitmen yang tinggi dari manajemen dan edukasi, baik ke dalam (manajemen rumah sakit) maupun keluar (masyarakat). Perubahanperubahan tersebut juga dinilai mampu meningkatkan citra rumah sakit di mata masyarakat. Menurut Utami, respon masyarakat juga dinilai baik terbukti dari total pendaftaran 87 persen telah menggunakan registrasi online .

Adapun beberapa hambatan yang muncul dalam penggunaan layanan ini adalah adanya keterbatasan eksternal maupun internal. Meskipun sudah memasuki era digital tetapi tidak semua masyarakat atau pasien dapat menggunakan atau memiliki akses terhadap internet, serta tidak semua orang memahami alur/teknologi pendaftaran ini. Aplikasi ini juga belum berbasis android dan masih terpisah-pisah antara pendafatran, informasi antrian, kamar dan sebagainya. Selain itu hambatan internal berupa komitmen, contohnya ketika dokter cuti mendadak, sedangkan pasien sudah mendaftar.

Hal lain yang perlu ditingkatkan adalah insentif dari pemerintah. RSUD Margono pernah mendapatkan insentif dari Kementerian PAN dan RB terkait lomba sinovik, namun belum mendapatkan insentif dari Pemerintah Provinsi Jawa Tengah secara khusus untuk inovasi pengembangan layanan berbasis teknologi informasi ini.

Terlepas kendala tersebut di atas, RSUD Margono telah sukses menjadi pelopor inovasi di bidang layanan kesehatan. Hal ini tidak terlepas dari berkembangnya budaya kerja yang baik, meliputi profesionalisme, tanggungjawab, egaliter, transparan, dan konstruktif. Sebagai contoh, sistem penilaian kinerja pegawai sudah menggunakan sistem $360^{\circ}$, dimana terjadi kesamaan hak di dalam menilai kinerja setiap pegawai. Selain itu, komitmen pimpinan dalam pengembangan budaya kerja juga menjadi faktor penentu. Sejarah pengembangan layanan berbasis teknologi informasi sudah dimulai sejak tahun 2012 dengan membentuk unit khusus menangnai IT. Saat ini RSUD Margono memiliki sumberdaya manusia sebanyak 28 orang tenaga IT, yang terbagi ke dalam beberapa divisi yaitu pengembangan aplikasi (android, website), hardware seperti komputer dan jaringan, dan serta database. Infrastruktur teknologi informasi sudah dilengkapi dengan jaringan fiber optik di semua gedung, bahkan menjangkau Paviluen Abiyasa sejauh $25 \mathrm{Km}$, jaringan LAN dan wi fi.

Kemajuan yang dicapai oleh RSUD Margono ini diakui oleh berbagai pihak. Bahkan menjadi lokasi studi banding dan magang dari berbagai rumah sakit di Indonesia. Kemajuan yang sudah dicapai oleh RSUD Margono ini sebenarnya bisa menjadi model rumah sakit yang lain, terutama rumah sakit milik 
Pemerintah Provinsi Jawa Tengah, dimana memiliki sistem manajemen yang hampir sama. Namun upaya tersebut rupanya sulit dilakukan, sebagaimana dikemukakan oleh Ragil dan Utami, bahwa setiap rumah sakit memiliki kondisi eksisting yang berbeda di dalam manajemen pengelolaan rumah sakit menggunakan teknologi informasi. Misalnya dari sisi teknis bahasa pemrograman yang berbeda, infrastruktur yang berbeda, tata kelola yang berbeda, dan terutama budaya kerja yang berbeda. Tidak mudah menyamakan kondisi antar rumah sakit agar sesuai dengan standar yang berlaku di RSUD Margono.

\section{7) RSUD Tugurejo Semarang}

RSUD Tugurejo Semarang mengembangkan berbagai sistem layanan berbasis elektronik, baik untuk layanan informasi, pendaftaran, maupun layanan penunjang rumah sakit. Pendaftaran online diselenggarakan melalui sistem aplikasi RSUD Tugurejo Booking Online. Masyarakat bisa mengunduh aplikasi tersebut melalui google play. Aplikasi pendaftaran ini membantu masyarakat mendaftar secara online, melihat jadwal dokter dan poliklinik. Masyarakat bisa memilih jadwal kunjungan, dokter, dan poliklinik yang dituju, sehingga sistem ini mampu mengurai antrian panjang pendaftaran sampai ke poliklinik. Selain menggunakan aplikasi berbasis android, RSUD Tugurejo juga masih menggunakan layanan berbasis selular melalui SMS Gateway, sehingga memungkinkan masyarakat yang belum menggunakan perangkat andorid untuk menggunakan layanan ini dalam proses pendaftaran dan layanan infromasi lainnya.

Untuk tindakan medis lanjutan berupa operasi, disediakan layanan IBS Online. Layanan ini memungkinkan pasien mendaftar operasi, dan mengetahui daftar antrian operasi sehingga dapat mempersiapkan diri dengan lebih baik.
Layanan lainnya untuk masyarakat adalah info tempat tidur, dimana masyarakat bisa melihat ketersediaan tempat tidur di rumah sakit. Layanan ini memungkinkan masyarakat mengetahui ketersediaan kamar ketika harus menjalani rawat inap. Layanan ini juga memungkinkan pasien mengetahui ketersediaan kamar dan memilih kelas perawatan. Layanan informasi lainnya adalah E-IKM rekam medik elektronik, dimana masyarakat bisa mengetahui informasi rekam mediknya secara online. Dengan layanan ini masyarakat bisa mengetahui riwayat kesehatannya dengan lebih cepat sebagai bahan untuk upaya kesehatan mereka.

\section{Pembahasan}

Implementasi layanan berbasis teknologi informasi di 7 rumah sakit milik Pemerintah Provinsi Jawa Tengah secara umum sudah dilakukan dengan baik. Semua rumah sakit telah mengembangkan layanan pendaftaran dan informasi secara online kapada masyarakat. Sebagian menggunakan sarana berbasis internat, sebagian ditambah dengan layanan berbasis aplikasi pada perangkat telepon pintar. Melalui layanan tersebut, masyarakat atau pasien bisa melakukan pendaftaran secara online, mengetahui nomor antrian, mengetahui jadwal klinik dan pemeriksaan, memilih dokter, mengetahui ketersediaan kamar, mengurus farmasi, hingga mendaftar tindakan medis. Layanan tersebut sangat membantu pasien dan menghemat waktu. Rumah sakit sudah merintis pengembangan layanan tersebut dimluai dari penggunaan SMS gateway sampai aplikasi android.

Selain layanan eksternal, beberapa rumah sakit juga telah mengembangkan sistem manajemen rumah sakit berbasis elektronik. Hal ini dilakukan untuk mendukung kecepatan layanan terhadap pasien. Sistem elektronik memungkinkan 
proses penjadwalan dokter, penjadwalan poliklinik, sistem rujukan, pelayanan farmasi, serta klaim biaya kesehatan dilakukan dengan cepat dan akurat.

RSUD Prof. Dr. Margono Soekarjo Purwokerto merupakan salahsatu rumah sakit terdepan dalam pengembangan ini. Pada awalnya mengembangkan layanan pendaftaran melalui sistem "PENETRASI ONLINE" (Pengembangan Sistem Short Message Service Gateway Menuju Registrasi Online). Beberapa tahun kemudian dikembangkan menjadi RSMS online atau pendaftaran online. Saat ini penggunaan pendaftaran online di RSMS Margono mencapai 87 persen, yang menunjukkan bahwa sistem tersebut sudah disambut dengan baik oleh masyarakat. Layanan juga dilengkapi dengan "Tele Apik", yaitu sebuah informasi kepada pasien untuk bisa melihat nomor antrian baik di loket pendaftaran maupun ke klinik. Selain melalui elektronik, pendaftaran manual juga masih diberikan, namun pada akhirnya data akan diinput secara elektronik oleh petugas. Tersedia 17 loket pendaftaran yang melayani masyarakat, serta tenaga pembantu / helper untuk membantu penggunaan apliksi atau melakukan pendaftaran online.

RSUD Moewardi Surakarta juga memiliki konsep pengembangan layanan elektronik yang terintegrsi baik kepada pasien maupun manajemen di internal. Layanan E-patient memungkinkan masyarakat melakukan pendaftaran online, informasi jadwal dokter, informasi antrian daftar, nomor antrian, informasi dokter, proses farmasi, pengaduan dan beberapa informasi lainya. Pasien menggunakan akun yang bisa berlaku untukl 1 keluarga. Melalui aplikasi ini, pasien bisa mendaftar, mengetahui nomor antrian, memilih jadwal, mengetahui jadwal dokter dan klinik, serta informasi lainnya. Jika pasien tidak menggunakan pendafataran melalui aplikasi tersebut, bisa langsung datang ke rumah sakit serta menggunakan anjungan yang telah disediakan (on site). Apabila kurang familiar dengan sistem pendaftaran tersebut, maka bisa mendaftar secara manual melalui layanan "Apem Gerobag", langsung (manual) di loket pendaftaran rumah sakit, kemudian petugas akan menginput data secara elektronik. Layanan lainnya adalah "Singa Teriak", yaitu portal aduan masyarakat terhadap layanan rumah sakit.

Pada kedua rumah sakit tersebut, sudah digunakan sistem nanajemen pendafatran pasien elektronik sepenuhnya, meskipun masih dibuka layaan manual tetapi pada akhirnya akan diinput oleh petugas secara online. Sistem layanan berbasis elektronik dikembangkan secara mandiri oleh tenaga internal. Oleh karena dikembangkan sendiri, maka pengembangan dan keberlanjutan sangat terjaga. Hal yang terpenting adalah pengembangan aplikasi tersebut relatif tidak mengeluarkan banyak biaya, bahkan secara teknis tidak mengeluarkan biaya. Biaya yang dikeluarkan hanya untuk membayar gaji pegawai.

Selain kedua rumah sakit di atas, rumah sakit lainnya juga menggunakan pelayanan online berbasis android maupun website. RSJD Dr. RM. Soedjarwadi Klaten telah mengembangkan aplikasi online berbasis android. Melalui aplikasi tersebut, pasien dapat melakukan pendaftaran online, memilih klinik dan dokter, mengetahui jadwal kunjungan dokter, informasi resep, mengetahui antrian poliklinik, mengetahui ketersediaan tempat tidur, dan informasi layanan. Masyarakat juga bisa memberikan masukan atau pengaduan kepada manajemen rumah sakit.

RSJD Surakarta mengembangkan "SPOL AZ" (sistem pendaftaran online dr Arif Zainudin) yang tersedia dalam format website maupun android. Keluarga pasien dipermudah melakukan pendaftaran dan 
mengakses jadwal dokter, poliklinik, informasi-informasi penting lainnya. Rumah sakit ini juga mengembangkan aplikasi "Griya WBK" yaitu aplikasi ini berisi informasi laporan kinerja dari setiap kelompok kerja atau pokja yang ada di RSJD Surakarta terkait integritas dan anti korupsi.

Di RSUD Kelet Jepara, aplikasi pendaftaran online berbasis website. Pasien dapat melihat jadwal poliklinik, jadwal dokter, dan memilih jadwal berkunjung. Sistem ini juga melayani pasien dari poliklinik ke farmasi sampai kasir. Selain itu dikembangkan website "SI PUTRI" (Sistem Informasi Pelayanan Publik Terintegrasi) dimana masyarakat bisa meminta pelayanan informasi terkait dengan pelayanan RSUD Kelet Jepara. Masyarakat juga bisa mengajukan usulan kegiatan melalui e-renggar sesuai dengan kebutuhan mereka.

RSUD Tugurejo mengembangkan booking online berbasis website dimana pasien mendaftar online, melihat jadwal dokter dan poliklinik, memilih jadwal kunjungan, dokter, dan poliklinik yang dituju, sehingga sistem ini mampu mengurai antrian panjang pendaftaran sampai ke poliklinik. Selain itu juga masih menggunakan SMS Gateway untuk masyarakat yang belum menggunakan perangkat internet. Layanan IBS online dikembangkan untuk pasien mendaftar operasi, dan mengetahui daftar antrian operasi. Selain itu ada layanan $E-I K M$ untuk rekam medik elektronik dimana pasien dapat mengetahui informasi rekam mediknya secara online.

RSJD Dr. Amino Gondohutomo Semarang termasuk yang agak tertinggal dalam layanan elektronik. Belum dikembangkan sistem pendaftaran ektronik baik melalui website maupun andorid, sementara masih menggunakan layanan pendaftaran melalui SMS center. Layanan yang dikembangkan melalui website berupa layanan data ketersediaan ruang rawat inap.

Pada sisi manajemen rumah sakit, juga dilakukan pengembangan sistem manajemen elektronik untuk mempercepat proses layanan dan manajemen internal. Di RSUD Margono tahun 2017 layanan "SI BINA CANTIK" (Sistem Bridging SIM RSMS, BPJS, dan INA-CBG's mendapatkan penghargaan inovasi pelayanan publik (Sinovik) dari Kementerian PAN dan RB. Layanan ini merupakan pelopor integrasi atau bridging data antara rumah sakit dengan BPJS Kesehatan di Indonesia. Dengan adanya sistem bridging ini memungkinkan rumah sakit mengetahui perkiraan biaya perawatan sehingga mampu memperkirakan biaya yang ditanggung BPJS. Selain itu juga dikembangkan electronic validation (E - val) yaitu validasi tagihan biaya pelayanan pasien kepada BPJS Kesehatan. Saat ini $e$ val tahap uji coba bekerjasama dengan BPJS Kesehatan (pusat). Uji coba ini merupakan pilot project untuk pematangan $e$ val agar bisa diaplikasikan secara nasional.

Pegembangan manajemen internal di RSUD Dr. Moewardi Surakarta juga cukup baik. E-doctor merupakan sistem aplikasi memberikan infomasi kepada dokter jumlah pasien, jasa pelayanan, absensi internal, dokter juga mendapatkan notifikasi saat operasi, order operasi, ada pemetaan jadwal untuk dokter, jadwal visit dokter, rincian jasa pelayanan dan lain sebagainya. Dokter juga mendapatkan notifikasi jumlah pasien hari itu yang akan mengunakan jasanya. E-employee juga dikembangkan sebagai penghubung antara manajemen dan karyawan terutama untuk jadwal, absensi, bahkan sampai order mobil dinas. Aplikasi electronic claim, yaitu klaim biaya layanan ke BPJS memungkinkan efisiensi proses klaim. Pengembangan ini menjadi pelopor si kawasan Solo Raya. 
Rumah sakit lain yang mengembangkan sistem manajemen internal berbasis teknologi informasi adalah RSJD Dr. RM. Soedjarwadi Klaten. Rumah sakit tersebut mengembangkan aplikasi manajemen rumah sakit dalam bentuk SIM - RS (Sistem Informasi Manajemen Rumah Sakit).

Berdasarkan penjelasan tersebut, implementasi layanan berbasis teknologi informasi sudah dikembangkan di hampir semua rumah sakit milik Pemerintah Provinsi Jawa Tengah, namun dengan tingkatan yang berbeda. Hal tersebut menunjukkan bahwa inovasi pelayanan telah menjadi bagian dari semangat pelayanan rumah sakit milik Pemerintah Provinsi Jawa Tengah. Capaian inovasi tersebut tidak serta-merta menjadi seperti yang terjadi saat ini. Semua melalui tahaptahap yang kemudian disempurnakan dan diperbaiki sesuai dengan kapasitas dan kemajuan teknologi.

Sesuai dengan pemaparan temuan lapangan sebelumnya, beberapa rumah sakit milik Pemerintah Provinsi Jawa Tengah seperti RSUD Margono telah menjadi pelopor inovasi. Sebagian mendapat penghargaan di tingkat nasional, serta menjadi acuan nasional. Sejarah pengembangan layanan berbasis teknologi informasi sudah dimulai sejak tahun 2012 dengan membentuk unit khusus menangani IT. Saat ini RSUD Margono memiliki sumberdaya manusia sebanyak 28 orang tenaga IT, yang terbagi ke dalam beberapa divisi yaitu pengembangan aplikasi (android, website), hardware seperti komputer dan jaringan, serta database. Infrastruktur teknologi informasi sudah dilengkapi dengan jaringan fiber optik di semua gedung, bahkan menjangkau paviliun Abiyasa sejauh 25 $\mathrm{Km}$, jaringan LAN dan wi fi.

Prestasi yang dicapai oleh RSUD Margono ini diakui oleh berbagai pihak. Bahkan menjadi lokasi studi banding dan magang dari berbagai rumah sakit di Indonesia. Kemajuan yang sudah dicapai oleh RSUD Margono ini sebenarnya bisa menjadi model rumah sakit yang lain, terutama rumah sakit milik Pemerintah Provinsi Jawa Tengah, dimana memiliki sistem manajemen yang hampir sama. Namun upaya tersebut rupanya sulit dilakukan, sebagaimana dikemukakan oleh Ragil dan Utami, bahwa setiap rumah sakit memiliki kondisi eksisting yang berbeda di dalam manajemen pengelolaan rumah sakit menggunakan teknologi informasi. Misalnya dari sisi teknis bahasa pemrograman yang berbeda, infrastruktur yang berbeda, tata kelola yang berbeda, dan trutama budaya kerja yang berbeda. Tidak mudah menyamakan kondisi antar rumah sakit agar sesuai dengan standar yang berlaku di RSUD Margono.

Proses yang dilalui oleh RSUD Moewardi juga cukup menarik. RSUD Moewardi pada awalnya bekerjasama dengan pihak ketiga (developer) di tahun 2012 - 2014 dengan dana sekitar 3 milyar rupiah dalam pengembangan sistem layanan dan manajemen digital. Akan tetapi setelah selesai kontrak tahun 2014 sistem tidak lagi dijalankan karena tidak ada lagi kerjasama dan sistem tidak berfungsi. Setelah itu diputuskan untuk membangun sendiri sistem aplikasinya dengan memanfaatkan infrastruktur yang ada (server sendiri). Pembangunan aplikasi-aplikasi tersebut tidak terlepas dari peran penting seorang dokter spesialis penyakit dalam (dr. R. Satrio Budi S., SPPD) yang memiliki keahlian di bidang teknologi informasi. Aplikasi yang dikembangkan berbasis pada prinsip sistem electronic medical record. Dengan peran SDM internal tersebut, pembangunan aplikasi tidak membutuhkan banyak biaya. Adapun aspek infrastruktur sudah memiliki server yang dibeli terbaru tahun 2018 dengan spesifikasi AP Pro link generasi 9 memory 365 Giga, double 
processor. Infrastruktur pendukungnya adalah jaringan Fiber Optic lintas gedung.

Berdasarkan pengalaman 2 rumah sakit tersebut di atas, pengembagan inovasi layanan tersebut tidak terlepas dari berkembangnya budaya kerja yang baik. Budaya kerja yang baik berawal dari komitmen yang tinggi dari manajemen dan edukasi, baik ke dalam (manajemen rumah sakit) maupun keluar (masyarakat). Sebagaimana RSUD Margono yang telah sukses menjadi pelopor inovasi di bidang layanan kesehatan memiliki keunggulan budaya kerja profesionalisme, tanggungjawab, egaliter, transparan, dan konstruktif. Berkembangnya inovasi di RSUD Margono sebagaimana digambarkan Utami dan Ragil, tidak terlepas dari budaya kerja dan budaya organisasi. Pentingnya peran pimpinan organisasi, budaya kerja yang egaliter dan profsional, sinergi yang baik telah mendorong lahirnya semangat berinovasi. Sebagai contoh, sistem penilaian kinerja pegawai sudah menggunakan sistem $360^{\circ}$, dimana terjadi kesamaan hak di dalam menilai kinerja setiap pegawai. Selain itu, komitmen pimpinan dalam pengembangan budaya kerja juga menjadi faktor penentu. Langkah selanjutnya didukung dengan upaya serius penyediaan sumberdaya manusia yang kompeten, dimana dibentuk tim khusus pengembangan sistem teknologi infromasi yang SDM nya direkrut dengan uji kompetensi yang ketat. Selain itu pemenuhan infrastruktur juga menjadi perhatian. Sehingga pengembangan layanan teknologi informasi dilakukan secara mandiri dari kekuatan internal, tidak tergantung pihak luar. Dengan demikian aset menjadi sepenuhnya milik lembaga, serta pengembangan berkelanjutan tetap berjalan. Kondisi yang hampir sama juga terjadi di RSUD Moewardi Surakarta.

Beberapa kendala dan hambatan mewarnai proses pengembangan layanan tersebut,baik yang bersifat internal maupun eksternal. Hambatan internal yang sering dialami adalah komitmen kebijakan dan para pelaksana, ketersediaan SDM, serta ketersediaan sarpras.

Sebagaimana diungkapkan Utami (RSUD Margono) bahwa hambatan internal salahsatunya adalah komitmen, contohnya ketika dokter cuti mendadak, sedangkan pasien sudah mendaftar maka pelayanan menjadi terganggu. Secara umum pergantian pimpinan rumah sakit juga bisa jadi adanya pergantian kebijakan, termasuk terkait penggunaan aplikasi ini. Di beberapa rumah sakit lainnya seperti RSJD Surakarta terkendala ketersediaan SDM, serta mentalitas dimana terjadi kesenjangan antara konsep pelayanan model lama dan pelayanan saat ini menjadi salah satu penghambat. SDM yang kurang kompeten, terutama generasi terdahulu.

Sebagai upaya mengatasi kendala SDM, RSDU Moewardi Surakarta melakukan perbaikan terkait dengan pengelolaan SDM, dimana tunjangan tenaga pengelola ditingkatkan berbeda dengan pegawai divisi lainnya. Tenaga pengelola direkrut sesuai kompetensi, dimana berbasis TI dan analisis sistem. Terkait dengan pengembangan sistem juga sudah dibentuk group sharing diantara para pengelola teknologi informasi rumah sakit, baik tingkat Solo Raya maupun Jawa Tengah.

Dari aspek sarpras, beberapa kendala utama terkait dengan ketersediaan perangkat keras seperti server yang sering down sehingga menghambat pelayanan online. Kendala lain adalah ketersediaan aplikasi yang handal serta database yang memadai. Kelengkapan data sangat penting, sebagai contoh data-data profil dokter masih sangat jarang karena data diisi sendiri profilnya, sementara banyak dokter yang belum sempat mengisi. Demikian juga dengan layanan penunjang 
belum masuk sistem, dimana pasien yang harus ditindaklanjuti layanan penunjang belum bisa melalui proses online, namun daftarnya sudah ada di aplikasi. Dari aspek dokumen masih digunakan kertas karena klaim BPJS harus ada cetak pendaftaran, selain dokumen elektronik.

Hambatan eksternal yang dirasakan oleh hampir semua rumah sakit adalah terkait dengan pemahaman masyarakat dan sistem terkait di luar rumah sakit. Tidak semua masyarakat atau pasien dapat menggunakan atau memiliki akses terhadap internet, serta tidak semua orang memahami alur/teknologi pendaftaran ini. Sebagian masyarakat masih sering salah alur pendaftaran ketika menggunakan media online ini. Hal ini juga disebabkan karena minimnya sosialisasi aturan dalam pendaftaran online itu sendiri.

Hambatan eksternal lainnya adalah adanya kebijakan dan keterkaitan dengan sistem lain. Beberapa regulasi dari luar rumah sakit yang menghambat pemanfaatan dari suatu layanan. Adanya perubahan-perubahan dari sistem lain dengan cepat, misalnya sistem aplikasi BPJS yang berubah sehingga pihak rumah sakit juga harus menyesuaikan.

$$
\text { Sesuai dengan tujuannya, }
$$
pengunaan aplikasi berbasis teknologi informasi tersebut tentunya memberikan dampak terhadap reformasi birokrasi, khususnya pelayanan publik. Di hampir semua rumah sakit, manfaat yang dirasakan baik secara eksternal maupun internal. Secara eksternal manfaatnya berupa kecepatan pelayanan, kepastian waktu tunggu, transparansi, dan keadilan, sehingga meningkatkan kepuasan pasien, serta mengurangi waktu antrian.

Pelayanan publik di rumah sakit untuk pendaftaran dimulai dengan penggunaan Short Message Service (SMS), kemudian beranjak menggunakan akses aplikasi media sosial Whats App sampai yang termutakhir dengan penggunaan aplikasi buatan sendiri berbasis sistem Android. Hal ini memberikan kemudahan karena pasien/masyarakat bisa mengakses kapanpun dan di manapun. Fokus pelayanan kepada masyarakat yang lebih terlayani dengan sistem yang semakin baik berbasis teknologi informasi terus tumbuh. Sistem yang dikembangkan di rumah sakit tersebut memudahkan pasien untuk berobat, mulai dari pendaftaran sampai instalasi farmasi. Serangkaian perubahan penting terjadi di dalam pelayanan, antara lain waktu tunggu pasien yang menjadi lebih singkat mulai pendaftaran sampai bertemu dokter. Informasi penting bisa cepat diketahui masyarakat misalnya ketersediaan kamar. Rumah sakit juga mudah mendapatkan masukan dari masyarakat, baik keluhan, aduan atau usulan kegiatan. Pengalaman di beberapa rumah sakit seperti RSUD Moeardi dan RSUD Margono menunjukkan sistem ini diterima dan relatif tidak menimbulkan kesulitan bagi masyarakat.

Dengan demikian, kontribusi langsung penggunaan teknologi informasi dalam pelayanan publik adalah memberikan layanan yang lebih baik. Sistem pelayanan online terbukti mampu memberikan dukungan bagi pelayanan yang cepat, tepat, mudah, murah, adil, serta transparan. Kondisi ini sesuai dengan semangat reformasi birokrasi dimana salah satu area nya adalah peningkatan kualitas layaan publik dengan pelayanan yang lebih cepat, lebih murah, lebih mudah, dan lebih berkualitas

Bagi rumah sakit penerapan sistem berbasis teknologi informasi ini meningkatkan efisiensi kerja, meningkatkan kecepatan dan kemudahan dalam memberikan pelayanan. Sistem yang dikembangkan berpengaruh pada kinerja rumah sakit, antara lain kecepatan dan ketepatan kinerja karyawan, meningkatkan profesionalisme, 
kemudahan monitroing dan evaluasi, serta dispilin pegawai seperti dokter datang tepat dan tahu berapa jumlah pasien hari itu. Bagi masyarakat tercipta sebuah kemudahan dan bagi pegawai mendapatkan kemudahan adanya sistem kerja yang lebih efisien dan efektif dengan adanya penggunaan teknologi informasi. Di semua rumah sakit yang menerapkan sistem manajemen internal berbasis teknologi informasi seperti RSUD Margono, RSDU Moewardi, RSJD Dr. RM. Soedjarwadi Klaten, dan RSJD Surakarta bahwa proses bisnis rumah sakit menjadi lebih cepat. Perubahan yang terjadi setelah penggunaan aplikasiaplikasi tersebut yang dirasakan adalah proses kerja menjadi lebih singkat, tahaptahap pekerjaan menjadi jelas, serta adanya perubahan lain seperti mental aparat dan budaya kerja. Kepercayaan publik juga meningkat yang dibuktikan dengan menurunnya komplain.

Penggunaan sistem berbasis teknologi informasi dalam manajemen internal rumah sakit juga memiliki kontribusi terhadap reformasi birokrasi. Sesuai dengan salashastu area perubahan reformasi birokrasi yaitu "penataan tata laksana", penggunaan sistem berbasis teknologi informasi telah berperan meningkatkan efisiensi dan efektivitas sistem, proses, dan prosedur kerja. Dengan demikian, pengembangan sistem ini perlu diperluas ke semua rumah sakit melalui berbagai penyesuaian dengan kondisi internal.

Tantangan yang dihadapi dalam implementasi pelayanan online maupun sistem manajemen internal berbasis teknologi infomasi adalah kondisi setiap rumah sakit yang berbeda-beda. Sebagaimana digambarkan di atas, bahwa meskipun sama-sama milik Pemerintah Provinsi Jawa Tengah, namun kondisi ke7 rumah sakit berbeda-beda. Berdasarkan pengalaman di masing-masing rumah sakit, mereka memiliki sejarah sendirisendiri dalam mengembangkan sistemnya. Di dalam pengembangan sistem menggunakan bahasa pemrograman yang berbeda-beda. Selain itu kapasitas SDM dan sarpras juga sangat berbeda. Perbedaan juga terjadi pada aspek kebijakan dan manajemen rumah sakit. Masing-masing rumah sakit mengembangkan sistem secara mandiri dan tidak berkomunikasi dengan rumah sakit lainnya, akibatnya bentuk sistemnya juga berbeda.

Oleh karena perbedaan kondisi dan arah pengembangan sistem, maka akan sangat sulit untuk melakukan penyeragaman penggunaan sistem layanan dan manajemen internal pada seluruh rumah sakit milik Pemerintah Provinsi Jawa Tengah. Di sisi lain sebagian rumah sakit misalnya RSUD Margono telah menjadi rujukan rumah sakit dari daerah lain. Banyak rumah sait yang telah melakukan studi banding, bahkan magang untuk mereplikasi sistem yang telah dikembangkan di RSUD Margono. Akan tetapi di Jawa Tengah sendiri belum terdapat suatu keselarasan baik dari aspek kebijakan, sistem, SDM, maupun sarpras untuk meerapkan sistem yang sama. Hal ini menajdi tantangan bagi Pemerintah Provinsi Jawa Tengah untuk membangun suatu keselarasan antar rumah sakit agar kualitas pelayanan antar rumah sakit menjadi terstandar.

\section{PENUTUP}

\section{Kesimpulan}

Semua rumah sakit milik Pemerintah Provinsi Jawa Tengah telah berupaya mengembangkan inovasi sistem pelayanan online berbasis teknologi informasi. Beberapa rumah sakit bahkan mengembangkan sistem manajemen internal berbasis elektronik yang saling terkoneksi. Setiap rumah sakit memiliki sejarah pengembangan, kebijakan dan 
manajemen, kapasitas SDM dan sarpras yang berbeda, sehingga hasilnya berbeda. Sistem yang dibangun secara mandiri oleh tenaga internal lebih bisa berkembang dan keberlanjutannya sangat terjaga. Langkah tersebut relatif tidak mengeluarkan biaya banyak, selain untuk membayar gaji pegawai.

Faktor pendukung pengembangan inovasi layanan berbasis teknologi informasi adalah budaya kerja yang baik. Budaya kerja ini berawal dari komitmen yang tinggi dari manajemen, adanya edukasi, profesionalisme, tanggungjawab, egaliter, transparan, dan konstruktif. Kemudian secara teknis didukung penyediaan sumberdaya manusia kompeten yang direkrut dengan uji kompetensi yang ketat, serta penyediaan sarpras yang memadai.

Beberapa hambatan internal yang sering dialami adalah komitmen kebijakan dan para pelaksana, ketersediaan SDM, serta ketersediaan sarpras. Hambatan eksternal adalah aksesibilitas dan pemahaman masyarakat yang kurang, serta perubahan sistem terkait di luar rumah sakit.

Pengunaan teknologi informasi memberikan kontribusi terhadap reformasi birokrasi. Manfaat yang dirasakan masyarakat berupa kecepatan pelayanan, kepastian waktu tunggu, transparansi, dan keadilan, sehingga meningkatkan kepuasan pasien, serta mengurangi waktu antrian. Perubahan tersebut sesuai dengan area reformasi birokrasi "penimgkatan kualitas layanan publik" yaitu lebih cepat, lebih murah, lebih mudah, dan lebih berkualitas. Manfaat bagi rumah sakit meningkatkan efisiensi kerja, meningkatkan kecepatan dan kemudahan dalam memberikan pelayanan. Hal tersebut sesuai dengan area perubahan reformasi birokrasi "penataan tata laksana", yaitu meningkatkan efisiensi dan efektivitas sistem, proses, dan prosedur kerja.

\section{Saran}

Komitmen kebijakan dan penyediaan sumberdaya yang memadai merupakan prasyarat utama berkembangnya inovasi, oleh karena itu perlu ditingkatkan penghargaan dan insentif dari pemerintah dan pemerintah daerah terhadap penyelenggara pelayanan publik.

Pemerintah Provinsi Jawa Tengah perlu menguatkan kebijakan tentang implementasi budaya kerja yang baik, yang dibarengi dengan penyediaan sumberdaya berupa ketersediaan SDM serta sarpras yang memadai.

Untuk menyikapi kendala aksesibilitas masyarakat dan pemahaman masyarakat diperlukan upaya edukasi yang berkelanjutan terkait prosedur layanan rumah sakit, hak dan kewajiban pasien dan rumah sakit. Keterbatasan aksesibilitas bisa disikapi dengan menyediakan layanan bantuan atau layanan berbasis komunitas yaitu satu akun untuk beberapa orang.

Untuk menyikapi perbedaan kondisi dan arah pengembangan sistem di setiap rumah sakit yang menyebabkan tidak terciptanya standar kualitas diperlukan adanya komitmen penyelarasan antara Pemerintah Provinsi Jawa Tengah dan ketujuh rumah sakit, atau bahkan dengan RSUD milik Kabupaten/Kota untuk menerapkan sistem-sistem terbaik secara bertahap. 
DAFTAR PUSTAKA

Adrizal, Fatma Sriwahyuni, Yufri Aldi. 2019. Analisis Pelayanan Resep Konvensional dan Elektronik serta Pengaruhnya terhadap Kualitas Pelayanan Kefarmasian di RSUD M. Natsir Solok Indonesia. Jurnal Sains Farmasi \& Klinis. Vol. 06 No. 03 | Desember 2019

Akhmaddhian, Suwari. 2012. Pengaruh Reformasi Birokrasi Terhadap Perizinan Penanaman Modal di Daerah; Studi Kasus di Pemerintahan Kota Bekasi. Jurnal Dinamika Hukum Vol 12 No 3 September 2012.

Andhika, Lesmana Rian. 2017. Systematic Review: Budaya Inovasi Aspek Yang Terlupakan Dalam Inovasi Kepegawaian. Jurnal Civil Service. Vol. 11, No.1, Juni 2017 : Hal. 49-61

Arikunto, Suharsini. 2007. Manajemen Penelitian. Jakarta: Rineka Cipta.

Cahyono, Eddy. 2017. Era Disruption dan Manajemen Stratgic Birokrasi. http://setkab.go.id/manajemenstrategik-komunikasi-publik-diera-digital/. 11 Oktober 2017 .2017. Manajemen Strategik Komunikasi Publik di Era Digital, http://setkab.go.id/manajemenstrategik-komunikasi-publik-diera-digital/. 3 Juli 2017

Daniel, Moehar, Darmawati, Nieldalina. 2005. PRA, Pendekatan Efekti Mendukung Penerapan Penyuluhan Partisipatif dalam Upaya Percepatan Pembangunan Pertanian.Jakarta. Bumi Aksara

Holle, Erick S. 2011. Pelayanan Publik Melalui Electronic Government: Upaya Meminimalisir Praktek Maladministrasi Dalam
Meningkatan Public Service. Jurnal Sasi Vol.17 No.3 Bulan Juli-September 2011

Indrajit, Richardus Eko. 2006. Electronic Government; Konsep Pelayanan Publik Berbasis Internet dan Teknologi Informasi. Aptikom. Jakarta

Muchsam, Yoki \& Fazriana Mareta. (2019). Analisis Pengaruh Kepahaman Sistem Rujukan Online Peserta BPJS Terhadap Kepuasan Pelayanan BPJS. Seminar Nasional Informatika Medis (SNIMed) 5 Oktober 2019. Teknik Informatika, UII. Sleman, Yogyakarta. ISSN. 2339-2207

Nabyla, Fuaida, Rito Cipta Sigitta Hariyono. 2019. Desain Aplikasi Sistem Pendaftaran Online Menggunakan Smartphone Untuk Meningkatkan Mutu Pelayanan pada Rumah Sakit. Journal of Information System Vol. 4, No. 2, Nopember 2019: 168-177

Nurbarani, Myrna. 2009. Reformasi Birokrasi Pemerintah Kota Surakarta. Tesis Program Studi Magister Ilmu Politik Program Pascasarjana Universitas Diponegoro Semarang. http://eprints.undip.ac.id/24269/1 I MYRNA NURBARANI.pdf

Nuril, Ahmad. 2018. Reformasi Birokrasi Pemerintah Kota Semarang ; Studi Kasus Di Badan Pelayanan Perizinan Terpadu Kota Semarang. Journal of Politic and Government Studies Vol 7, No 2 (2018): Periode Wisuda April 2018. Jurusan Ilmu Pemerintahan Fakultas Ilmu Sosial dan Ilmu Politik, Universitas Diponegoro. 
Peraturan Presiden Nomor 81 Tahun 2010) tentang Grand Design Reformasi Birokrasi 2010-2025

Rizki, Ahmad. 2019. Inovasi Facilitating Service Di Rumah Sakit Umum Daerah Abdul Moeloek (Studi Tentang Reservasi Online Support System). Skripsi.

Fakultas Ilmu Sosial Dan Ilmu Politik Universitas Lampung Bandar Lampung

Sedarmayanti. 2009. Reformasi Administrasi Publik, Reformasi Birokrasi, dan Kepemimpinan Masa Depan. PT Refika Aditama. Bandung

Taufan. 2017. Implementasi Reformasi Birokrasi Dan Kualitas Pelayanan Publik di Dinas Kependudukan dan Pencatatan
Sipil Kabupaten Sleman Tahun 2014-2016. Jurusan Ilmu Pemerintahan Fakultas Ilmu Sosial Dan Politik Universitas Muhammadiyah Yogyakarta. http://repository.umy.ac.id

Usman, Husaini \& Purnomo Setiady Akbar. 2008. Metodologi Penelitian Sosial. Bumi Akasara. Jakarta

Yusriadi \& Misnawati. 2017. Reformasi Birokrasi Dalam Pelayanan Publik (Studi Pelayanan Terpadu Satu Pintu). Jurnal Ilmiah Ilmu Administrasi Publik Volume 7 Nomor 2 Juli - Desember 2017. Hal 99-108. Homepage: http://ojs.unm.ac.id/index.php/ia $\mathrm{p} /$ index 